\title{
A Comparative Analyses of Dexamethasone and Neem Leaf Extract for Treating Cigarette-Smoke Induced Liver Injury in Swiss Mice
}

\author{
Anushree Verma \\ Banaras Hindu University - South Campus \\ Subhashini Sini \\ Banaras Hindu University \\ Vishal Srivashtav ( $\square$ vishal_bt85@yahoo.com ) \\ Banaras Hindu University - South Campus \\ Yashasvi Khajuria \\ Banaras Hindu University - South Campus
}

\section{Research Article}

Keywords: Azadirachta indica, Dexamethasone, Cigarette smoke, Swiss mice, Anti-inflammatory.

Posted Date: January 24th, 2022

DOI: https://doi.org/10.21203/rs.3.rs-1195222/v1

License: (c) (i) This work is licensed under a Creative Commons Attribution 4.0 International License. Read Full License 


\section{Abstract}

Cigarette smoke induces cytokines and lipid peroxidation in liver cells contributing to one of the causes for mortality across the globe. Dexamethasone is widely used for medication yet it decreases the levels of glutathione peroxidase and superoxide dismutase in macrophages. Therefore, present study focused on the comparison between dexamethasone and Azadirachta indica leaf extract for treating hepato-injury caused by cigarette smoke in mice. The phytochemical screening of $A$. indica ethanolic leaf extract revealed the abundance of sterols, proteins, alkaloids, flavanoids and diterpenes that could have antioxidant and anti-inflammatory activities. In this context, Swiss mice were treated with cigarette smoke, dexamethasone and $A$. indica leaf extract. Dexamethasone treated mice exclusively resulted in mortality rate of $20 \%$. These mice expressed elevated inflammatory cells with higher levels of liver markers, alanine aminotransferase (ALT; $56.00 \mathrm{IU} / \mathrm{L}$ ) and aspartate aminotransferase (AST; $64.90 \mathrm{IU} / \mathrm{L}$ ). Moreover, these mice revealed the prevalence of relative oxygen species (ROS) at 32500 RFU and eosinophil peroxidase (EPO) level at 1.97 absorbance units with declined superoxide dismutase (SOD) levels of $4.3 \mathrm{n} \mathrm{kat} / \mathrm{mg}$. Whereas, tissue recovery was spotted in the mice treated with $A$. Indica leaf extract with highly declined levels of liver markers, AST (10.20 IU/L) and AST (15.90 IU/L). Furthermore, these mice resulted in lesser amount of ROS at 21900 RFU and EPO levels at 1.08 absorbance unit with increased SOD levels of $7.17 \mathrm{n}$ kat/mg. This is the first report demonstrating in vivo effects of Azadirachta indica ethanolic leaf extract in treating cigarette smoke induced hepatic chronic inflammation in animal model which gave better results when compared to dexamethasone.

\section{Introduction}

Inflammation is a primary defensive response expressed by living cells against the noxious intracellular and extracellular agents. Every so often, these cellular responses continue to remain constant for a long, developing into chronic diseases which require potent pharmacological treatments (Demir 2020). However, these treatments may have adverse effects and therefore alternative natural therapies are acknowledged to cure long term illness. Various herbs and plants are persistently in use since the Vedic era for the treatment of severe diseases including blood and urine infections, myocardial infarction, kidney failure, lung diseases, and many more (Sen et al. 2017).

There are several reasons beholding the cause for liver damage such as asthma, diabetes, alcohol consumption, chronic obstructive diseases (Yong et al. 2020). Smoking causes architectural variations leading to the malfunctioning of the organ by increasing oxidative stress, chronic inflammation in tissues and enhances the production of stress kinases, inflammatory cytokines, and lipid peroxidation which ultimately injures liver tissues. Cigarette smoke alters the activity of NF-KB, a redox-sensitive transcription factor, playing a significant role in oxidation regulation and inflammation. It modifies the NF-KB expression by increasing the expression of other regulatory genes in non-parenchymal hepatocytes. Moreover, cigarette smoking causes oxidative injury by reducing superoxide dismutase (SOD) activity in addition to elevation in eosinophil peroxidase (EPO) and serum aminotransferases activity (Ponist et al. 2019). Under these circumstances, it becomes obligatory to diagnose liver damage which is facilitated by 
the examination of aspartate aminotransferase (AST) and alanine aminotransferase (ALT) levels (liver injury markers) since RBCs are rich in AST that leaks into plasma before haemolysis (Raja et al. 2011). Dexamethasone is a commercial anti-inflammatory corticosteroid widely used for the treatment of chronic obstructive pulmonary disease (COPD), but inspite of that its long-term use or high doses has been reported to cause various harmful side-effects including insulin resistance, hyperglycemia and weight change (Malkawi et al. 2018). As a consequence of this, there is a requirement of substitutes that could potentially be effective against aforesaid diseases with limited side-effects. Several plants have been exploited extensively in traditional Indian culture (Ayurveda) which are of medicinal value and have been used to treat a number of diseases with least side-effects (Balunas et al. 2005). Azadirachta indica (neem) is native to Indian sub-continent and has been used widely for centuries as medicine to cure number of diseases because of its antioxidant, antimicrobial, anti-inflammatory, antigastric ulcer, antipyretic, hypoglycaemic and anti-tumor activities (Eid et al. 2017). There are several bioactive compounds present in leaf extract of neem such as tannins, sterols, alkaloids, flavonoids, diterpenes, and proteins (Benisheikh et al. 2019). Research has shown that $A$. indica extract has safe nature that set the basis for its use over thousands of years. Flavonoids reported to have antioxidant and free radical scavenging activity (Kanagasanthosh et al. 2015) and with regard to this, it is assumed that the phytochemicals present in neem leaf extract probably are responsible for its potential anti-inflammatory

activity. This study was designed to examine the effect of ethanolic leaf extract of neem in comparison to dexamethasone against hepato-injury caused by cigarette smoke in mice.

\section{Materials And Methods \\ Plant Materials}

The fresh leaves of Azadirachta indica were collected from BHU campus and then identified by Prof. NK Dubey (with a voucher number of Melia. 2019/1), Department of Botany, Institute of Science, Banaras Hindu University, Varanasi.

\section{Preparation of Azadirachta indica ethanolic extract}

Plant leaves were grind using mortar-pestle and subjected to alcoholic extraction by soxhlet apparatus. 5 gm of powdered leaves was taken in a cotton cloth and placed into flat-bottom beaker of the soxhlet containing $50 \mathrm{ml}$ of $50 \%(\mathrm{v} / \mathrm{v})$ ethanol and kept overnight. Soxhlated ethanolic extract so prepared was then transferred into Petri plates followed by their incubation at $37^{\circ} \mathrm{C}$ for $7-8$ hours.

\section{Animal Groups}

Swiss mice (18-28 gms) of either sex were randomly divided into 5 groups of 6 mice each (Table 1). The mice were housed in a plastic cage at room temperature $\left(25 \pm 2^{\circ} \mathrm{C}\right)$ for the experiment. 
Table 1

Grouping of animal model.

\begin{tabular}{|lll|}
\hline Group A & Control \\
\hline Group B & Smoke-induced \\
\hline Group C & Dexamethasone-induced smoker \\
Group D & Neem extract $(100 \mathrm{mg} / \mathrm{kg} \mathrm{BW})$ induced smoker \\
Group E & Neem extract $(400 \mathrm{mg} / \mathrm{kg} \mathrm{BW})$ induced smoker \\
\hline
\end{tabular}

\section{Preparation of Drugs}

The stock solution of dexamethasone was prepared by dissolving $1 \mathrm{mg}$ of it in $1 \mathrm{ml}$ of distilled water of which $250 \mu \mathrm{l}$ was used as a working solution. The ethanolic neem leaf extract was used in two different concentrations which were $400 \mathrm{mg} / \mathrm{kg}$ body weight and $100 \mathrm{mg} / \mathrm{kg}$ BW in two mice groups respectively (smoker and non-smoker) shown in Table 1.

\section{Smoke exposure}

Mice were placed in a smoke chamber (a rectangular box) with a partition wall dividing it into two halves, containing 16 holes in it. A cigarette puff plugged into a motor was adjusted on either side of the box for its ignition whose smoke was allowed to pass through these small holes towards the other side of the wall where mice were placed. Cigarette Smoke exposure was continued for 5-7 minutes after the drug administration which was given 45 minutes before the CS exposure. This treatment was given thrice in a week with an interval of two days and continued for 7 weeks.

\section{Administration of drug into the animal model}

Drugs from working solution were administered into mice intraperitoneally 45 minutes before cigarette smoke exposure. This was repeated thrice a week for 7 weeks with an interval of two days.

\section{Phytochemical Screening}

\section{Test for tannins}

$2 \mathrm{ml}$ of neem leaf extract was taken to which $2 \mathrm{ml}$ distilled water was added followed by introduction of few drops of Ferric chloride to confirm the presence of tannins. Green precipitates showed the presence of tannins (Sivakumar and Gajalakshmi 2013).

\section{Test for Saponins}

Distilled water and neem leaf extract were added into test tube in 1:1 ratio and shaken vigorously. The persistence of foam indicated presence of saponins (ljoma et al. 2017).

Test for sterols 
$1 \mathrm{mg}$ of crude neem leaf extract was dissolved into $10 \mathrm{ml}$ of chloroform followed by the addition of an equal volume of conc. sulphuric acid through wall of test tube. The upper layer turned red while the lower layer appeared yellowish in colour with green fluorescence (Saklani et al. 2012).

Test for detection of protein

Concentrated Nitric acid $\left(\mathrm{HNO}_{3}\right)$ was added to neem leaf extract. The appearance of yellow colour confirmed the presence of proteins (Sati and Kumar 2015).

Test for phenols

Few drops of Ferric chloride $\left(\mathrm{FeCl}_{3}\right)$ were added to the extract. Formation of bluish-black precipitates showed the presence of phenols (ljoma et al. 2017).

Test for alkaloids

The extract was dissolved into diluted $\mathrm{HCl}$. Subsequently the mixture was filtered and later few drops of Wagner's reagent were added. Reddish-brown precipitates at the bottom of test tube indicated the presence of alkaloids (De et al. 2010).

Test for flavonoids

A few drops of $\mathrm{NaOH}$ solution were added to few $\mathrm{ml}$ of neem leaf extract followed by the addition of diluted acid. Intense yellow colour was observed on the addition of $\mathrm{NaOH}$ which turned colourless on the addition of diluted acid (Mohammed 2019).

Test for carbohydrate

$5 \mathrm{ml}$ of distilled water was added to neem leaf extract and the mixture was then subjected to filtration through Whatman filter paper No. 1. Benedict's solution was added to the filterate so obtained. Orange-red precipitates gave positive results (Nadhiya et al. 2019).

Test for diterpenes

Neem leaf extract was added with water and few drops of freshly prepared copper acetate solution. Emerald green precipitates at the bottom of test tube confirmed the presence of diterpenes (Shahverdi et al. 2019).

Test for triterpenes

Chloroform was added to the neem leaf extract and mixure was then filtered. Conc. Sulphuric acid was added to the filterate. Golden-yellow precipitates appeared in the test tube as per the method (Kumar et al. 2015).

\section{Analysis of Bodyweight of mice}


The body weight of mice was noted every week to observe gain/reduction due to the administration of dexamethasone, neem extract, and cigarette smoke. It was observed from the first to the last day of the experiment. The differences in body weights of mice were calculated before sacrificing them.

\section{Analysis of Mortality rate}

Mortality rate was observed during the whole experiment.

\section{Estimation of eosinophil peroxidase (EPO) in liver}

$100 \mathrm{mg}$ of mice tissue was homogenized (1:1) into $1.9 \mathrm{ml}$ PBS followed by its centrifugation at $12000 \mathrm{X}$ $\mathrm{g}$ for 10 minutes. Supernatant was taken for enzymatic assay and equal amount of substrate $(0.075$ $\mathrm{mmol} / \mathrm{L}$ Tris- $\mathrm{HCl} \mathrm{pH} 8,1.5 \mathrm{mmol} / \mathrm{L} \mathrm{O}$ - phenylenediamine, and $6.6 \mathrm{mmol} / \mathrm{L} \mathrm{H}_{2} \mathrm{O}_{2}$ in) was added. Further reaction was stopped with the addition of $50 \mu \mathrm{L}$ of $1 \mathrm{~mol} / \mathrm{L} \mathrm{H}_{2} \mathrm{SO}_{4}$, and absorbance was recorded at 490 nm (Adamko et al. 2004).

\section{Histopathology of liver}

The histopathology of liver was performed as per the protocol (Ragavan et al. 2006). Tissue from liver was dissected and placed into 10\% NBF (Neutral Buffered Formalin) followed by its dehydration using different grades of alcohol which was transferred to the cassette filled with filtered paraffin wax and left for whole day. After microtomy, tissue was fixed on slides with DPX (Distyrene, Plasticiser, and Xylene) to observe under microscope.

\section{Total Protein Content in liver tissue}

Total protein concentrations were measured as $\mu \mathrm{g} / \mathrm{ml}$ in serum by Folin's assay (Lowry's method) as per the previously defined procedure (Waterborg et al. 1994). Reagents were added into samples and observed using UV-spectrophotometry.

\section{Liver function test by quantifying AST and ALT in serum}

$5 \mu \mathrm{l}$ serum was diluted upto $10 \mu \mathrm{l}$ with distilled water. A reagent mixture was prepared from Autospan liquid gold standard kit (Arkray Healthcare Pvt. Ltd.) and ELISA was performed for the estimation of AST and ALT. $10 \mu \mathrm{l}$ of serum as a sample was mixed in $100 \mu \mathrm{l}$ reagent prepared according to assay kit [SGPT (DST) (IFCC Method) Rechon Diagnostics P. Ltd.] and ELISA was performed followed by its observation at $390 \mathrm{~nm}$. The enzyme activity is expressed as International Units/Litre (IU/L).

\section{Estimation of Reactive Oxygen Species (ROS) in the liver}

Tissue homogenate (1:1) was prepared as per method (Shin et al. 2016) and was centrifuged followed by the addition of PBS and DCFDA to the pellet. Observations were taken at an absorbance of $485 \mathrm{~nm}$ and emission at $535 \mathrm{~nm}$.

\section{Estimation of superoxide dismutase (SOD)}


Phosphate Buffer was added for the homogenization of tissue and other reagents were mixed including L-methionine, hydroxylamine hydrochloride, hydrogen peroxide, and EDTA followed by incubation for 10 mins under the white fluorescent light inside an aluminum foil-wrapped box. Freshly prepared Griess reagent was added and absorbance was measured at $543 \mathrm{~nm}$ (Das et al. 2006).

\section{Statistical analysis}

All the experiments were repeated twice to compare results. Experimental data were reported as mean \pm SEM of $n=5$. Multiple group comparisons were determined using Student's t-test.

\section{Results}

\section{Phytochemical analysis of an ethanolic extract of A. indica}

Phytochemical investigation of Azadirachta indica ethanolic leaf extract revealed the presence of tannins, sterols, proteins, alkaloids, flavonoids and diterpenes while saponins, phenols, triterpenes and carbohydrates were found to be absent (Table 2). The presence of these biologically active compounds in leaf extract of $A$. indica probably holds the accountability for its anti-inflammatory property.

\section{Bodyweight analysis}

Bodyweight of mice was analyzed for 7 weeks after their treatment with dexamethasone and two different doses of $A$. Indica, viz $100 \mathrm{mg}$ and $400 \mathrm{mg}$ (Fig. 1). During first week, weight of mice remained constant in control, smoke-induced and in dexamethasone administered group as well. However, a subtle weight decline was observed during fourth week in CS-induced mice group while dexamethasone treated mice group resulted in a gradual weight reduction during second and fourth week. Additionally, body weight of mice was decreased during first week in both ethanolic neem extract induced groups, while further it remained constant throughout the experiment.

Table 2. Phytochemical analysis of ethanolic extract from the leaves of Neem (Azadirachta indica) 


\begin{tabular}{|ll|}
\hline Bioactive Compounds & Present (+)/ Absent (-) \\
\hline Tannins & + \\
\hline Saponins & - \\
\hline Sterols & + \\
\hline Proteins & + \\
\hline Phenols & - \\
\hline Alkaloids & + \\
\hline Flavonoids & + \\
\hline Diterpenes & + \\
\hline Triterpenes & - \\
\hline Carbohydrates & - \\
\hline
\end{tabular}

\section{Mortality Rate analysis}

The mortality rate was observed weekly among all the mice groups during experiment (Fig. 2). Dexamethasone treated group exhibited $20 \%$ mortality rate in the fifth week of experiment while no mortality was oberserved in rest of the mice groups.

\section{Eosinophil peroxidase activity (EPO)}

EPO activity was analysed to examine the recruitment and activation of eosinophil peroxidase. As illustrated in Fig. 3, the activity and level of eosinophil peroxidase elevated in the smoke-induced group of mice with 1.99 absorbance units when compared to control group. In parallel, dexamethasone administered group also showed rise in EPO activity at 1.97 absorbance units which was comparable to smoke-induced group while $A$. indica leaf extract treated group exhibited least EPO activity of 1.09 absorbance units.

\section{Histopathology of Liver}

Liver tissues of mice from all the groups were sectioned appropriately and stained with HematoxylinEosin staining. The histological images presented pathological variations in CS-induced and dexamethasone treated mice tissues (Fig. 4B and $4 \mathrm{C}$ respectively) when compared to normal tissue from control mice group (Fig. 4A). Cellular inflammation and disrupted architechture were seen in altered liver tissues of mice. On contrary, liver tissues from the mice group treated with $100 \mathrm{mg}$ dose of ethanolic neem leaf extract showed reduced inflammatory cells (Fig. 4D) and furthermore, tissues from the mice group treated with $400 \mathrm{mg}$ herbal dose resulted in least cellular inflammation and disruption, thereby tissue recovery (Fig. 4E).

\section{Estimation of total protein content in liver}


Protein estimation in the blood serum was carried out in consequence of the proteinaceous inflammatory markers. As shown in Fig. 5, the protein content in the smoke-induced group of mice was higher being $15.82 \mu \mathrm{g} / \mathrm{mg}$ compared to the control group, while it was reduced in the group administered with dexamethasone with the value of $11.99 \mu \mathrm{g} / \mathrm{mg}$ yet it was elevated to $14.11 \mu \mathrm{g} / \mathrm{mg}$ in $400 \mathrm{mg}$ neem extract treated group. Probably, there was formation of protective proteins in mice administered with a high and low dose of neem extract.

\section{Liver Function Markers}

Aspartate aminotransferase (AST) activity

Effects of tobacco smoke, dexamethasone and leaf extract of $A$. Indica on the activity of aspartate aminotransferase (AST) was analysed. The examination revealed a higher serum AST activity in the smoke-induced group at $68.00 \mathrm{IU} / \mathrm{L}$ in comparison to the control group of mice. AST level in dexamethasone treated mice group, $56.00 \mathrm{IU} / \mathrm{L}$, was comparable to the mice group treated with cigarette smoke while the activity of AST was minimum in $400 \mathrm{mg}$ herbal extract treated group at $10.2 \mathrm{IU} / \mathrm{L}$ (Fig. $6)$.

Alanine aminotransferase (ALT) activity

Alanine aminotransferase (ALT) activity was investigated to check the impacts of neem leaf extract. The results demonstrated higher activity of ALT in the smoke-induced and dexamethasone treated group at $72.50 \mathrm{IU} / \mathrm{L}$ and $64.90 \mathrm{IU} / \mathrm{L}$ respectively as compared to the normal group, while serum ALT was highly reduced in $400 \mathrm{mg}$ dose of neem leaf extract with $15.90 \mathrm{IU} / \mathrm{L}$ level, as shown in Fig. 7.

\section{Estimation of Reactive Oxygen Species (ROS) in mice liver}

Reactive Oxygen Species (ROS) were analysed to examine the free radical generation during smokeinduced inflammation and the effect of neem extract on it. ROS were found to be the maximum in the smoke-induced group of mice at 34600 RFU (relative fluorescence unit) when compared with control group. Dexamethasone induced group showed a prevalence in the number of ROS at 32500 RFU whereas the group treated with $100 \mathrm{mg}$ dose of leaf extract resulted in reduced ROS levels at 22400 RFU. Furthermore, the group treated with $400 \mathrm{mg}$ dose showed the least amount of ROS at 21900 RFU (Fig. 8). Estimation of Superoxide Dismutase (SOD)

Superoxides are produced as by-product of oxygen metabolism and, if not regulated, can cause cell damage. Superoxide dismutase (SOD) constitutes a vital antioxidant defense against oxidative stress in the body. As illustrated in Fig. 9, the superoxide dismutase activity in this study was maximum in control mice as $7.50 \mathrm{n} \mathrm{kat} / \mathrm{mg}$. The SOD activity declined in smoke-induced mice which was recovered on treatment with $400 \mathrm{mg}$ dose of neem leaf extract upto the level of $7.17 \mathrm{n} \mathrm{kat} / \mathrm{mg}$. Dexamethasone treated group also resulted elevation in SOD activity to a level of $4.30 \mathrm{n}$ kat $/ \mathrm{mg}$, yet it was not comparable to herbal extract. 


\section{Discussion}

Smokers are at considerable risk of cardiovascular diseases (ischaemic heart disease, hypertension), respiratory disorders (bronchitis, emphysema, chronic obstructive lung disease, asthma), cancer (lung, pancreatic, breast, liver, bladder, oral, larynx, oesophagus, stomach, and kidney), peptic ulcers and gastroesophageal reflux disease (GERD), male impotence and infertility, blindness, hearing loss, bone matrix loss, and hepatotoxicity. Cigarette smoke is responsible for a variety of adverse and hazardous effects on organs which do not have direct exposure to it such as liver and that's way it is prone to toxic immunological and oncogenic effects (El-Zayadi 2006). It yields numerous chemicals that are structurally distinct involving free radicals having cytotoxic potential and are responsible for increase in necroinflammation and fibrosis. Moreover, tobacco smoke contributes in the development of secondary polycythemia which might be a contributing factor to secondary iron overload disease-promoting oxidative stress of hepatocytes (Gutteridge et al. 1989).

In the present study, effects of neem extract and dexamethasone on cigarette smoke induced hepatoinjury were analysed. Leaf extract of $A$. indica $(100 \mathrm{mg} / \mathrm{kg}$ and $400 \mathrm{mg} / \mathrm{kg})$ was administered into mice which had anti-inflammatory and antioxidative role in treating liver-injury (Biswas et al. 2002). The phytochemical screening of leaf extract of $A$. indica revealed the presence of several bioactive compounds involving tannin, saponin, sterols, protein, phenols, alkaloids, flavonoids, diterpenes, triterpenes, and carbohydrates (Vinoth et al. 2012). Although, flavonoid is a large group of naturally occurring compounds that exhibits anti-inflammatory and antioxidant activity, so far terpenes and saponins also get hold of some anti-inflammatory activity (Sultana et al. 2017). Within realm of possibility, the phytochemicals present in A.indica were accountable for manifesting anti-inflammatory as well as antioxidant property in cigarette smoke-induced liver injury as demonstrated in the animal model. Alanine aminotransferase (ALT) and aspartate aminotransferase (AST) were found to be commonly used biomarkers for liver damage (Alsalhen et al. 2014). However, presence of AST also in cardiac muscle, skeletal muscle and erythrocytes obliged ALT to be the most specific marker for liver damage (Goorden et al. 2013). In this study, the levels of AST and ALT were examined for the functioning of the liver where cigarette smoke caused liver injury was indicated by the elevated levels of AST and ALT. The mice group treated with dexamethasone resulted in lower levels of AST and ALT yet it was not comparable to the $A$. Indica extract treatment which showed a highly diminished levels of AST and ALT suggesting that the liver damage was controlled in more proportion on administration of $A$. indica. The inflammation was confirmed by observing the enhanced activity of EPO, a marker of eosinophilic inflammation (Saidani et al. 2019). In this study, the activity of EPO enhanced in smoke-induced mice was suppressed on administration of $A$. indica extract at both doses and perhaps the bioactive compounds of $A$. indica were responsible for the anti-inflammatory effect. Besides, another inflammatory marker was protein concentration which shared similar results as that of EPO. An advanced antioxidant system has been developed to relieve oxygen stress, however an excessive amount of reactive oxygen species (ROS) disrupts homeostasis which develops oxidative stress that ultimately leads to hepatic disorders by bringing irremediable changes in lipids, proteins and DNA content (Li et al. 2015). Redox state constitutes an essential background for numerous liver disorders owing the fact that it is associated with the course 
of inflammatory, metabolic, and proliferative liver diseases (Cichoz et al. 2014). In our investigation, generation of ROS was found to be elevated in the smoke-induced group providing the basis for inflammation in liver tissues. Furthermore, ROS production in this study was enhanced by the suppressed activity of superoxide dismutase (SOD) as observed in liver tissues of Labeo rohita during toxicity test (Bojan et al. 2017). The enzyme served as an anti-inflammatory agent and also prevented precancerous cell changes (Karimi et al. 2017). The analysis of SOD activity resulted in the inhibition of ROS generation on treatment with $A$. indica extract demonstrating the anti-inflammatory and anti-oxidative function of herbal dose.

\section{Conclusions}

Corticosteroids are anti-inflammatory drugs used to treat numerous conditions. Dexamethasone is one of them that have side effects on body organs. Herbal approach could be its best alternative being a source of medicines from the ancient times. The current investigation demonstrates that the doses $(100 \mathrm{mg}$ and $400 \mathrm{mg}$ ) of ethanolic leaf extract of Azadirachta indica are relatively protective than dexamethasone in order to cure hepato-injury caused by cigarette smoke on account of no mortality and no severe toxic effects appeared in model organism on its administration based on the biochemical parameters and histopathology. Elicited from this research it can be concluded that $A$. indica have high margin of safety than dexamethasone in treating cigarette smoke induced liver damage yet further studies with different doses of extract are needed.

\section{Declarations}

Acknowledgement Authors are thankful to Banaras Hindu University, Varanasi, U.P., India for providing all facility to conduct this work.

Funding The authors declare that no funds, grants, or other support were received during the preparation of this manuscript."

Competing interest The authors declare no competing interest.

Author contribution Subhashini suggested and designed the study. Anushree Verma performed the research experiments and analysis including extract preparation, phytochemical screening, biochemical and histopathology evaluation. Yashasvi Khajuria wrote the original manuscript and Vishal Srivashtav edited the final manuscript.

Ethical approval All procedures performed in studies involving animals were in accordance with the ethical standards of Central Animal Ethical Committee, Banaras Hindu University, Varanasi, India.

\section{References}


1. Adamko DJ, Wu Y, Gleich GJ, Lacy P, Moqbel R (2004) The induction of eosinophil peroxidase release: improved methods of measurement and stimulation. J Immunol Methods 291(1-2):101-108

2. Alsalhen KS, Abdalsalam AR (2014) Effect of cigarette smoking on liver functions: a comparative study conducted among smokers and non-smokers male in El-beida City, Libya. Int Curr Pharm 3(7):291-295

3. Balunas MJ, Kinghorn AD (2005) Drug discovery from medicinal plants. Life Sci 78:431-441

4. Benisheikh AAG, Muhammad FM, Kelluri H, Aliyu ZM, Mallam UB, Jibrin MW (2019) Phytochemical extraction and antimicrobial studies on crude leaf extract of Azadirachta indica (Neem) in semi-arid region of Borno state, Nigeria. Int J Res Rev 6(12):516-522

5. Biswas K, Chattopadhyay I, Banerjee R, Bandhopadhyay U (2002) Biological activities and medicinal properties of neem (Azadirachta indica). Curr Sci 82(11):1336-1345

6. Bojan N, Hemalatha D, Rangasamy B, Maharajan K, Ramesh M (2017) Hepatic oxidative stress, Genotoxicity and Histopathological Alteration in fresh water fish Labeo rohita exposed to Organophosphorus pesticide profenofos. Biocatal Agric Biotechnol 12:185-190

7. Cichoż-Lach H, Michalak A (2014) Oxidative stress as a crucial factor in liver diseases. World J Gastroenterol 20(25):8082-91

8. Das K, Samanta, Chainy GBN (2000) A modified spectrophotometric assay of superoxide dismutase using nitrite formation by superoxide radicals. Indian J Biochem Biophys 37:201-204

9. De S, Dey YN, Ghosh AK (2010) Phytochemical investigation and chromatographic evaluation of the different extracts of tuber of Amorphaphallus paeoniifolius (Araceae). Int J Pharm Biol Res 1(5):150157

10. Demir S (2020) The Process of Acute and Chronic Inflammation: Biomarkers and Their Relationship with Diseases. Role of Nutrition in Providing Pro-/Anti-Inflammatory Balance: Emerging Research and Opportunities. IGI Global 1-23. DOI: 10.4018/978-1-7998-3594-3.ch001

11. Eid A, Jaradat N, Elmarzugi N (2017) A Review of chemical constituents and traditional usage of Neem plant (Azadirachta Indica). Palest Med Pharm J 2:75-81

12. El-Zayadi AR (2006) Heavy smoking and liver. World J Gastroenterol 12(38):6098-6101

13. Goorden SM, Buffart TE, Bakker A, Buijs MM (2013) Liver disorders in adults: ALT and AST. Nederlands tijdschrift voor geneeskunde 157(43):A6443

14. Gutteridge JMC, Halliwell B (1989) Iron toxicity and oxygen radicals. Baillieres Clin Haematol 2(2):195-256

15. Ijoma KI, Ajiwe VIE (2017) Phytochemical Screening of Dialium Indum Leaf extract (Velvet tarmarind). Int J Phytopharm 7(1):06-13

16. Kanagasanthosh K, Shanmugapriyan S, Kaviranjan V (2015) Evaluation of acute toxicity, antiinflammatory activity and phytochemical screening of ethanolic extract of Azadirachta indica leaves. Int J Res Dev Pharm L Sci 4(5):1737-1742 
17. Karimi-Khouzani O, Heidarian E, Amini SA (2017) Anti-inflammatory and ameliorative effects of gallic acid on fluoxetine-induced oxidative stress and liver damage in rats. Pharmacol Rep 69(4):830-835

18. Kumar RK (2015). Preliminary test of phytochemical screening of crude ethanolic and aqueous extract of Moringa pterygosperma Gaertn. J Pharmacogn Phytochem 4(1):7-9

19. Li S, Tan HY, Wang N, Zhang ZJ, Lao L, Wong CW, Feng Y (2015) The role of oxidative stress and antioxidants in liver diseases. Int J Mol Sci 16(11):26087-26124

20. Malkawi AK, Alzoubi KH, Jacob M, Matic G, Ali A, Al Faraj A, Abdel Rahman A M (2018) Metabolomics based profiling of dexamethasone side effects in rats. Front Pharmacol 9(46): doi:10.3389/fphar.2018.00046

21. Mohammed IMI (2019) Isolation, Characterization of Flavonoids from Terminalia brownie, Ziziphus abyssinica, Cassia sieberiana Roots and Evaluation of Antimicrobial Activity. (Doctoral dissertation, Sudan University of Science and Technology).

22. Nadhiya R, Sengottuvel T, Gopalasatheeskumar K, Ariharasivakumar G (2019) Phytochemical analysis and antioxidant activity of hydroalcoholic fruit extract of Cucumis dipsaceus. European $\mathrm{J}$ Biomed 6(12):281-286

23. Ponist S, Zloh M, Bauerova K (2019) Impact of Oxidative Stress on Inflammation in Rheumatoid and Adjuvant Arthritis: Damage to Lipids, Proteins, and Enzymatic Antioxidant Defense in Plasma and Different Tissues. Animal Models in Medicine and Biology. Doi:10.5772/intechopen.89480

24. Rady MY, Johnson DJ, Patel B, Larson J, Helmers R (2006) Corticosteroids influence the mortality and morbidity of acute critical illness. Crit Care 10(4):1-9

25. Ragavan B, Krishnakumari S (2006) Effect of T. arjuna stem bark extract on histopathology of liver, kidney, and pancreas of alloxan-induced diabetic rats. African J Biomed Res. 9: 189-197

26. Raja MMM, Raja A, Imran MM, Santha AMI, Devasena K (2011) Enzymes Application in Diagnostic Prospects. Biotechnology 10(1):51-59

27. Saidani C, Béchohra L, Laraba-Djebari F, Hammoudi-Triki D (2019) Kidney inflammation and tissue injury induced by scorpion venom: comparison with a nephrotoxic model. Toxin Rev 38(3):240-247

28. Saklani S, Mishra AP, Sati B, Sati H (2012) Pharmacognostic, phytochemical and antimicrobial screening of Aphanamixis polystachya, an endangered medicinal tree. Int J Pharm Pharm Sci 4(3):235-240

29. Sati SC, Kumar P (2015) Assessment of Himalayan juniper, Juniperus squamata buch-ham ex d. don for phytochemical screening and antimicrobial potential against some infection causing pathogens. World J Pharmaceut Res 4:998-1011

30. Sen S, Chakraborty R (2017) Revival, modernization and integration of Indian traditional herbal medicine in clinical practice: Importance, challenges and future. J Tradit Complement Med 7(2):234244

31. Shahverdi MA, Omidi H, Tabatabaei SJ (2019) Stevia (Stevia rebaudiana Bertoni) responses to $\mathrm{NaCl}$ stress: Growth, photosynthetic pigments, diterpene glycosides and ion content in root and shoot. J Saudi Soc Agric Sci 18(4):355-360 
32. Shin IS, Ahn KS, Shin NR, Lee HJ, Ryu HW, Kim JW, Oh SR (2016) Protective effect of EC-18, a synthetic monoacetyldiglyceride on lung inflammation in a murine model induced by cigarette smoke and lipopolysaccharide. Int Immunopharmacol 30:62-68

33. Sivakumar T, Gajalakshmi D (2013) In vitro antioxidant and chemical constituents from the leaves of Ormocarpum cochinchinense elumbotti. Am J Plant Physiol 8(3):114-122

34. Sultana B, Anwar F, Przybylski R (2007) Antioxidant activity of phenolic components present in barks of Azadirachta indica, Terminalia arjuna, Acacia nilotica, and Eugenia jambolana Lam. Trees. Food Chem 104(3):1106-1114

35. Vinoth B, Manivasagaperumal R, Rajaravindran M (2012) Phytochemical analyaia and antibacterial activity of Azadirachta indica A Juss. Int J Res Plant Sci 2(3):50-55

36. Waterborg JH, Matthews HR (1994) The Lowry method for protein quantitation. Methods Mol Biol 32:1-4

37. Yong SH, Leem AY, Kim YS, Park MS, Chang J, Kim SU, Jung JY (2020) Hepatic Fibrosis Assessed Using Fibrosis-4 Index Is Predictive of All-Cause Mortality in Patients with Chronic Obstructive Pulmonary Disease. Int J Chron Obstruct Pulmon Dis 15:831-839

\section{Figures}

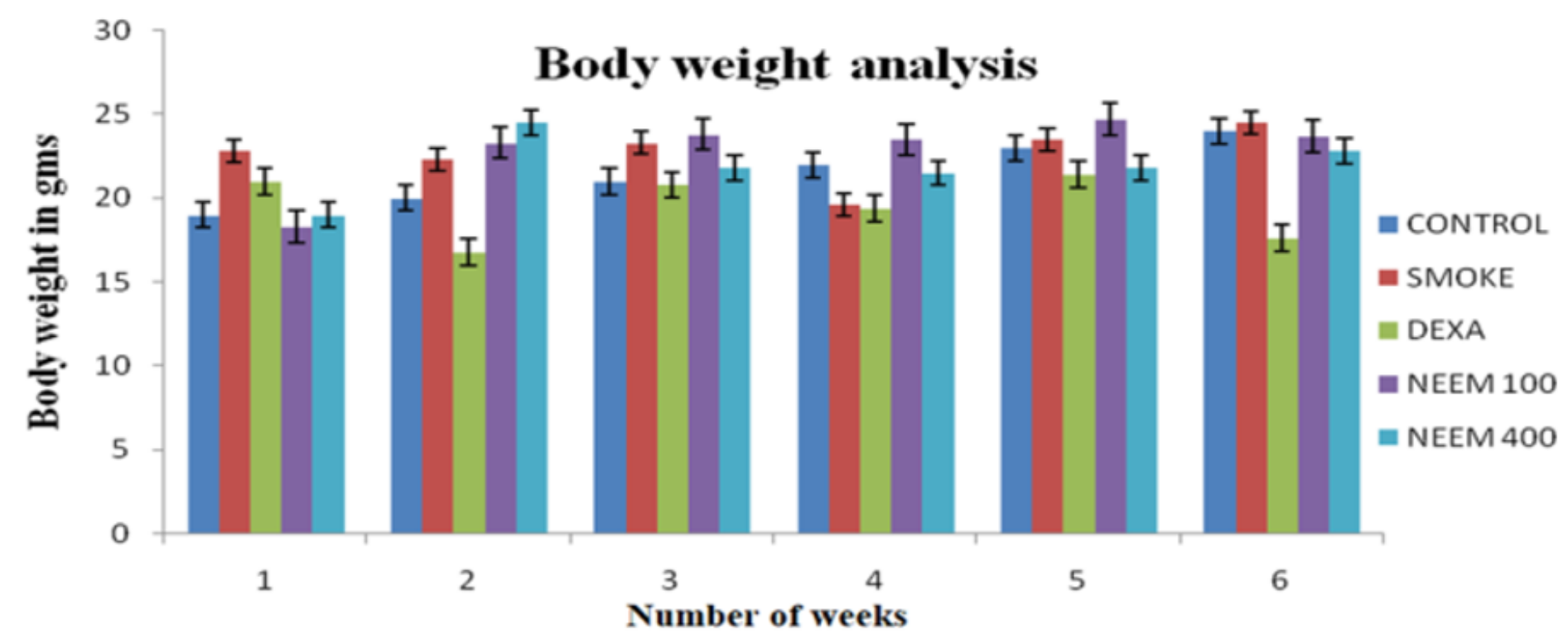

Figure 1

Graphical representation of the effect of the synthetic drug and herbal extract on the bodyweight of the model organism. 


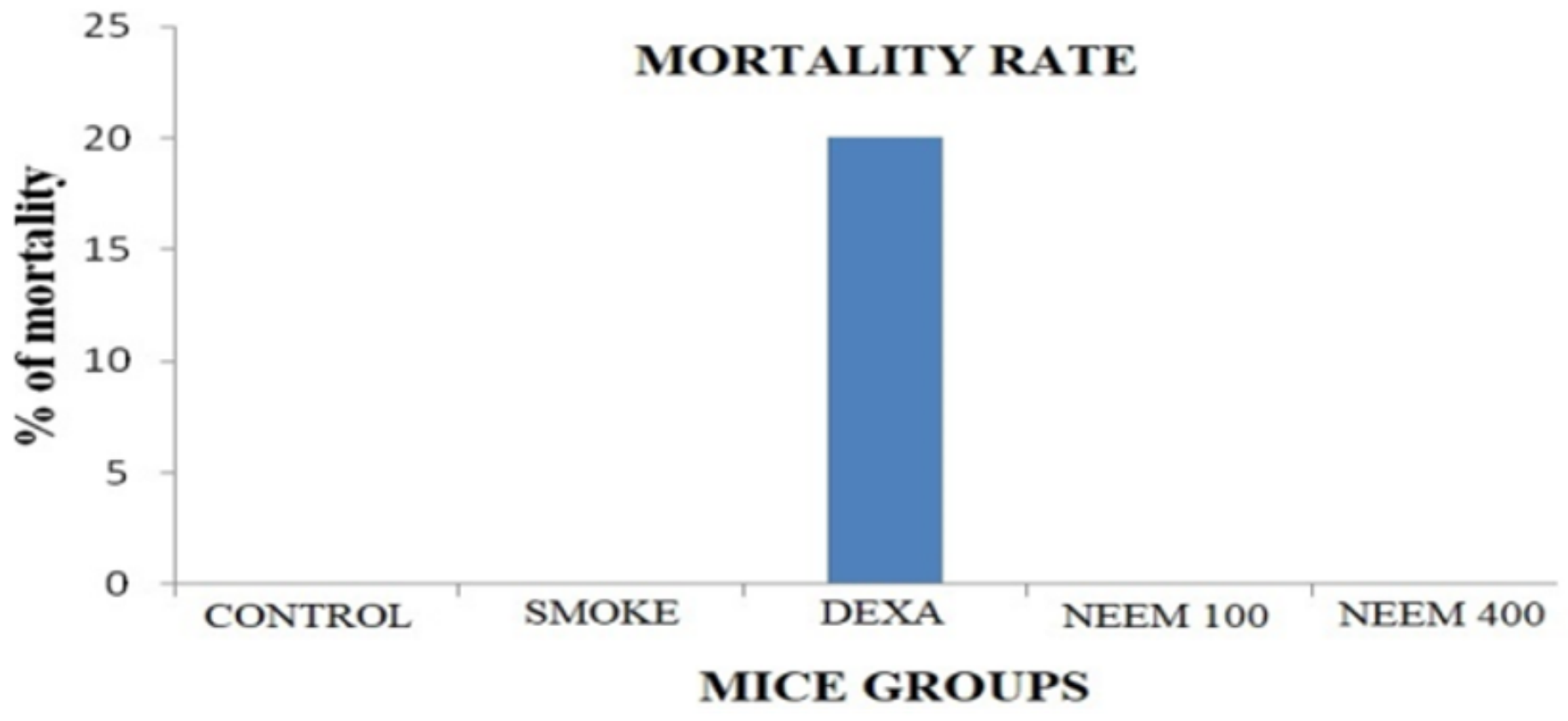

Figure 2

Effect of a synthetic and herbal drug on the life-span of mice.

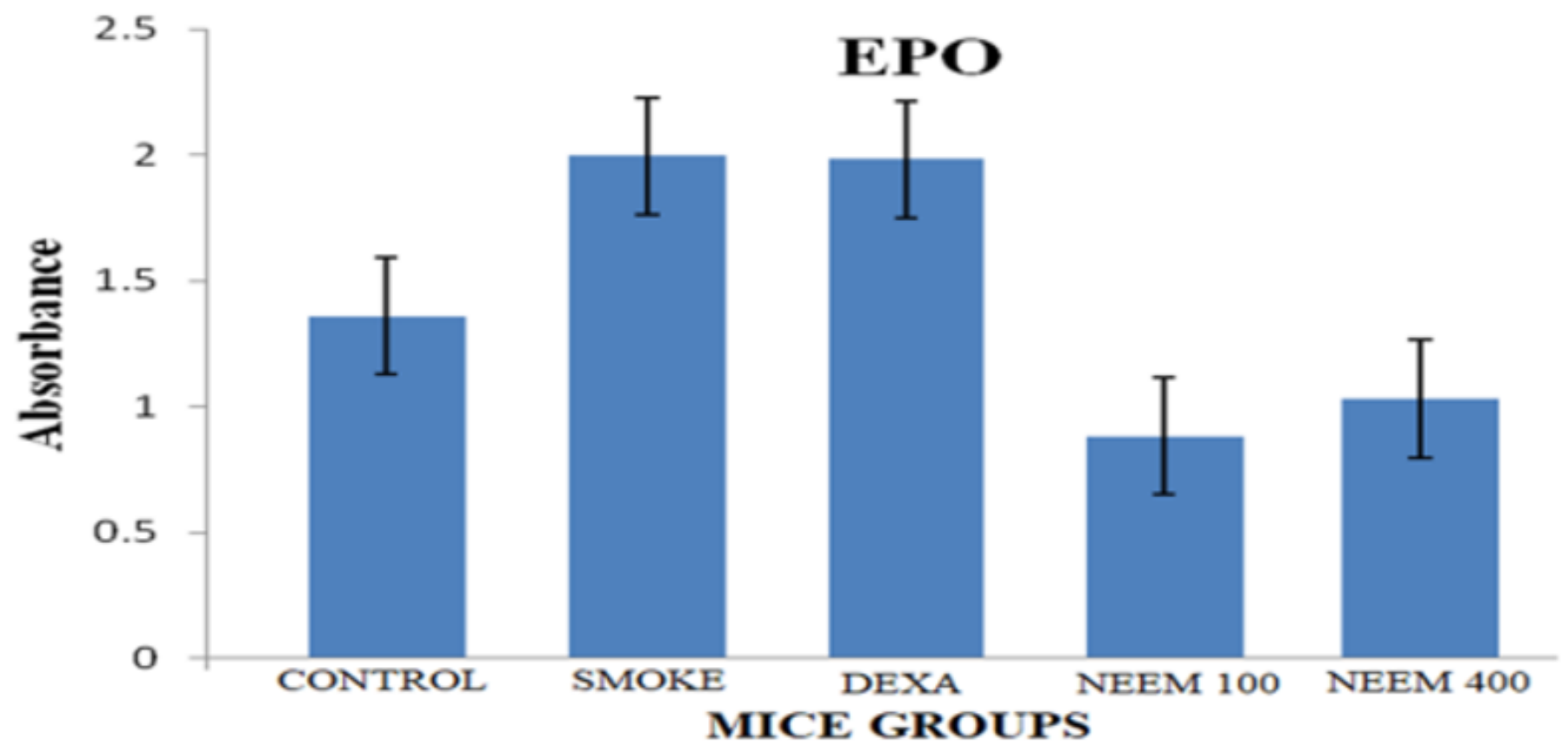

Figure 3

Effect of Dexamethasone and $A$. indica leaf extract on Eosinophil peroxidase activity in smoke-induced liver injury. 

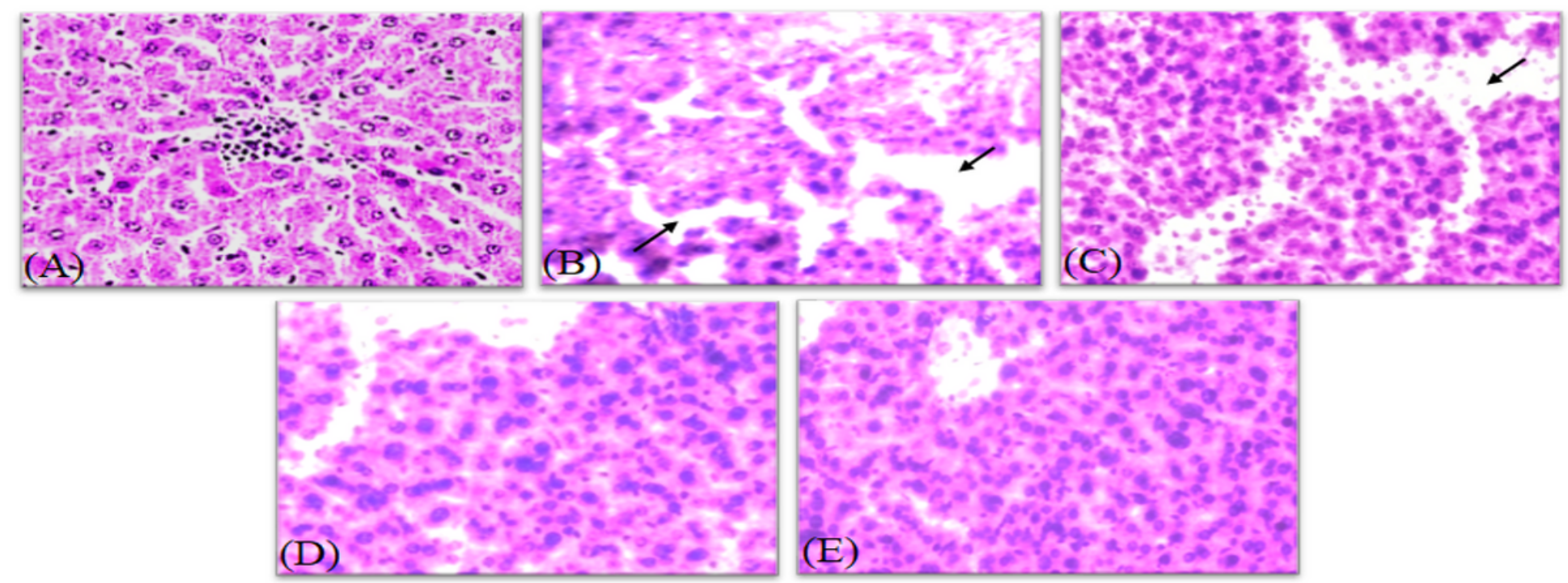

Figure 4

Morphology of liver tissue by Haematoxylin \& Eosin staining; A. Control mice liver; B. Highly disruption observed in smoke-induced mice liver; $\mathrm{C}$. Cells disruption and the presence of inflammatory cells were found in Dexamethasone-induced mice liver; D. Reduction in inflammatory cells was found in low dose neem treated mice liver; E. Damage recovery in high dose neem leaf extract induced liver.

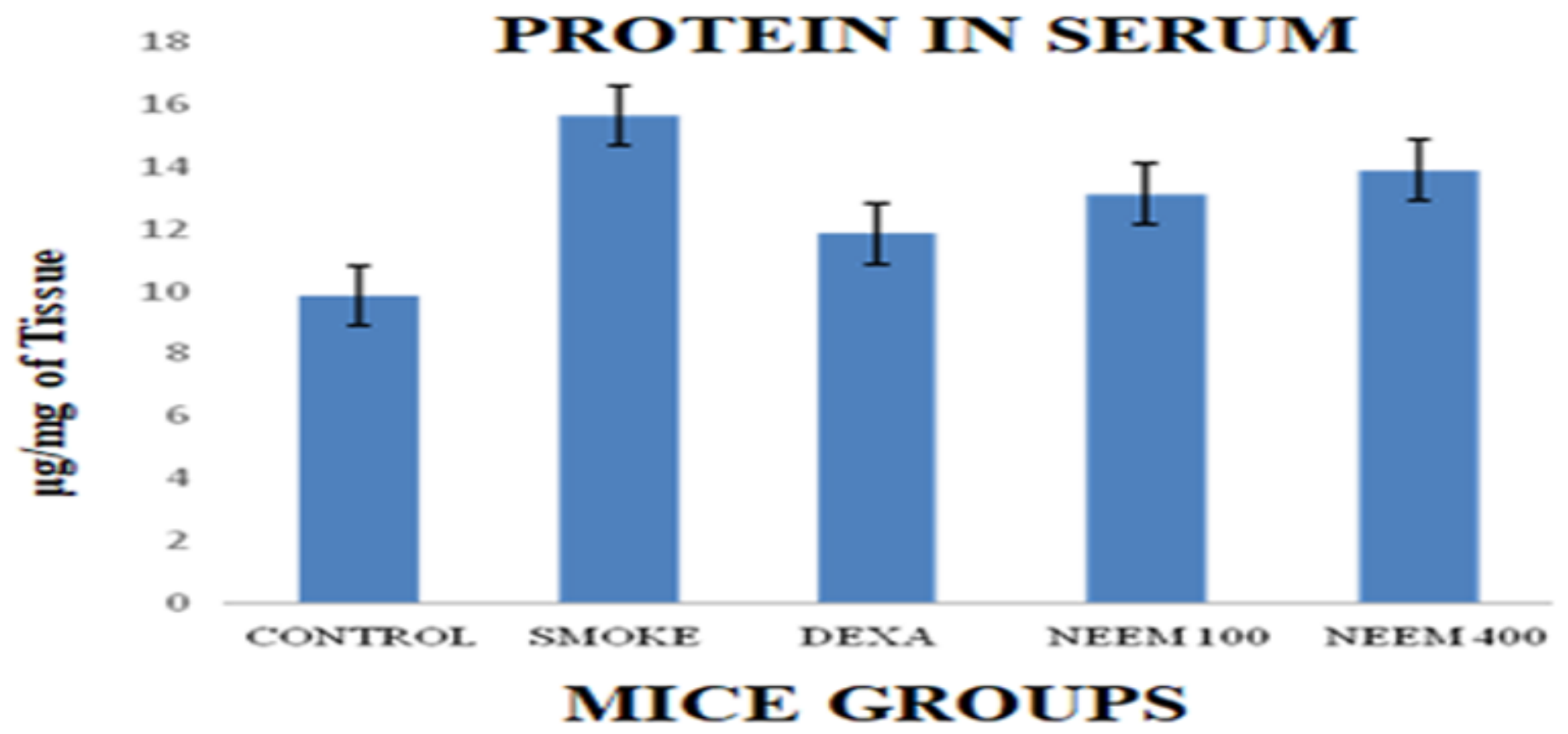

Figure 5 
Effect of Dexamethasone and A.indica on the protein content in the serum of a smoke-induced group of mice.

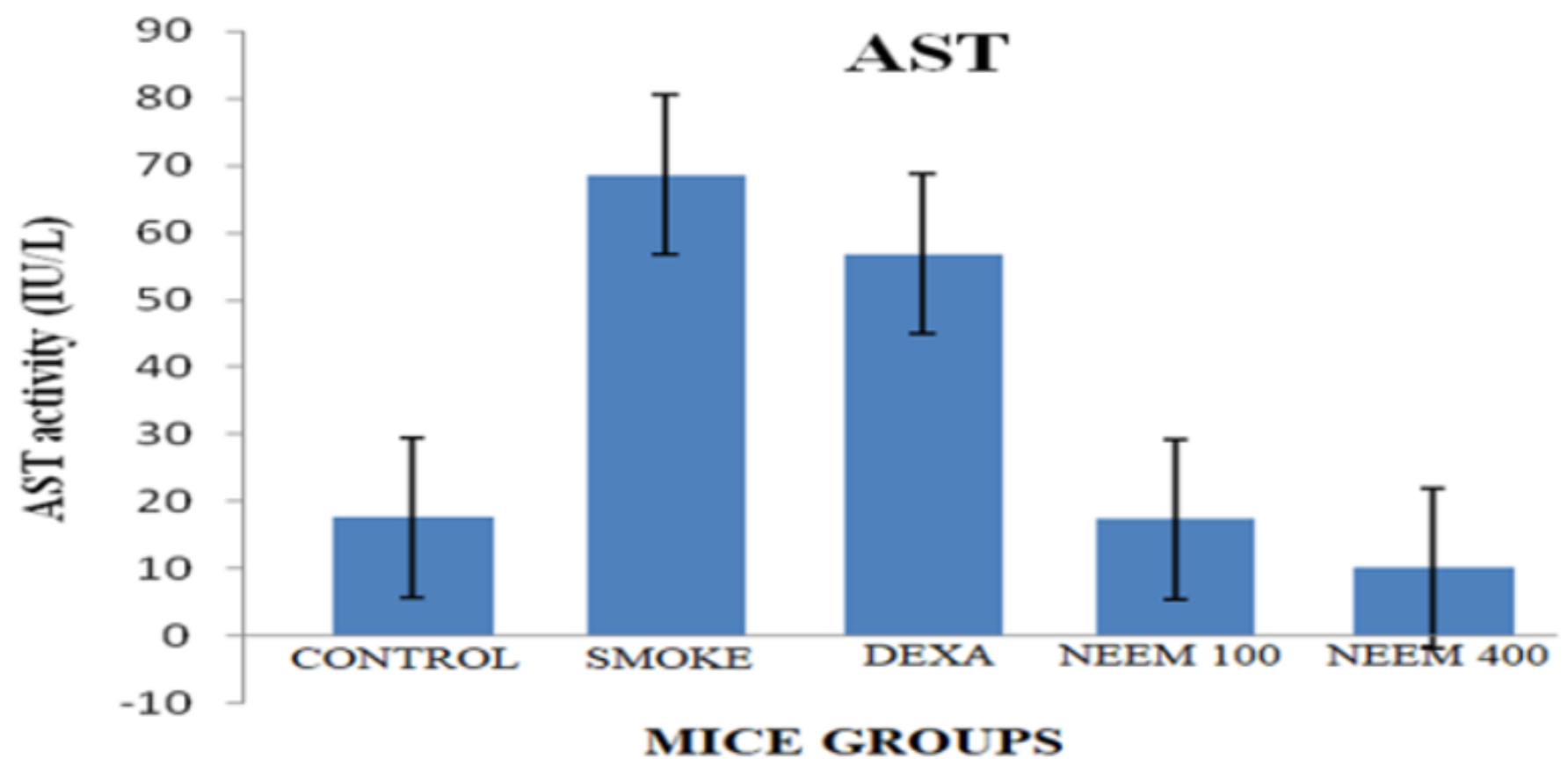

Figure 6

Effect of Dexamethasone and A.indica on aspartate aminotransferase (AST) activity in serum of smokeinduced mice. 


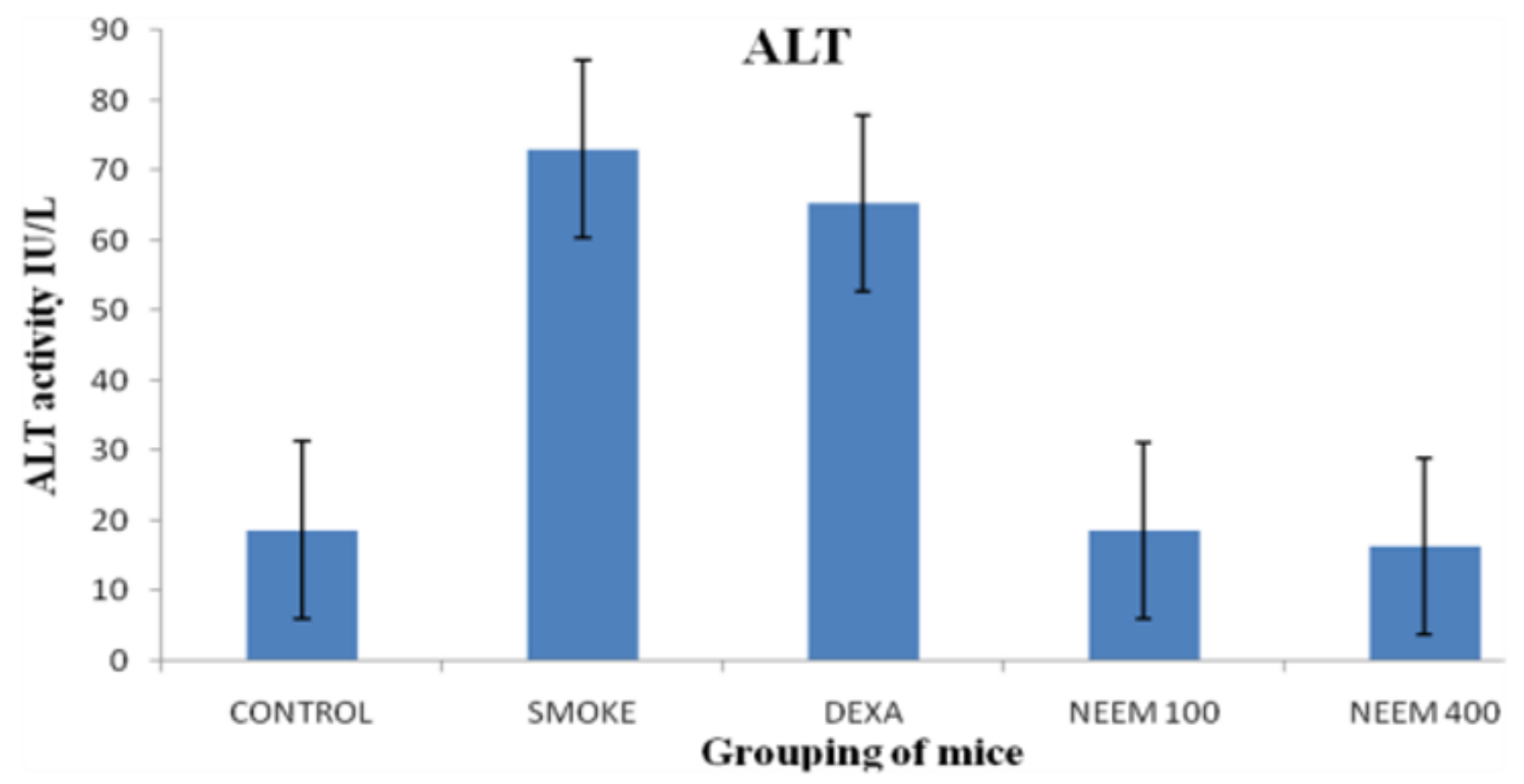

Figure 7

Effect of Dexamethasone and $A$. indica on alanine aminotranferase (ALT) activity in serum of smokeinduced liver injury.

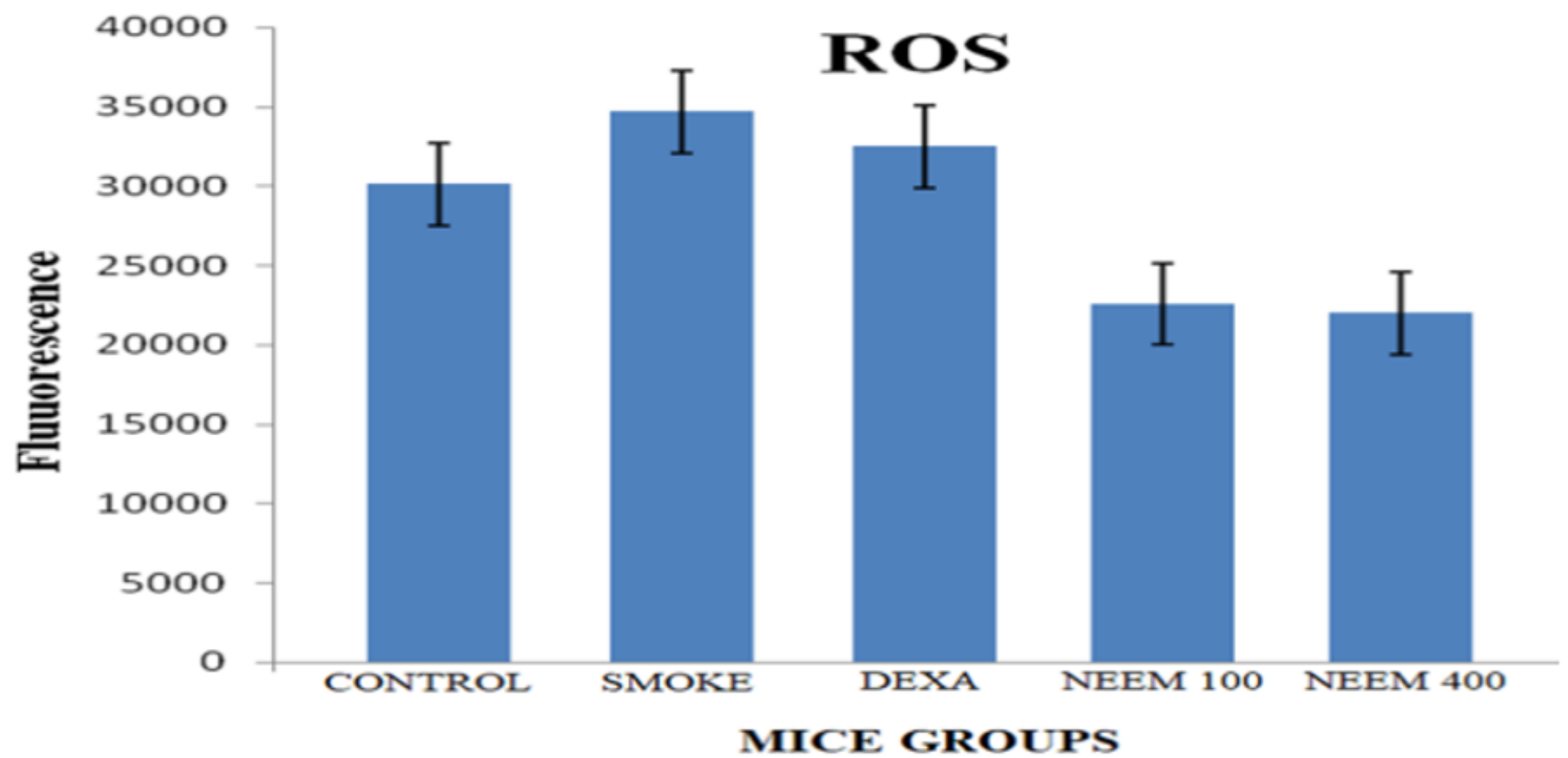

Figure 8 
Effect of Dexamethasone and $A$. indica on ROS production in serum of smoke-induced liver injury.

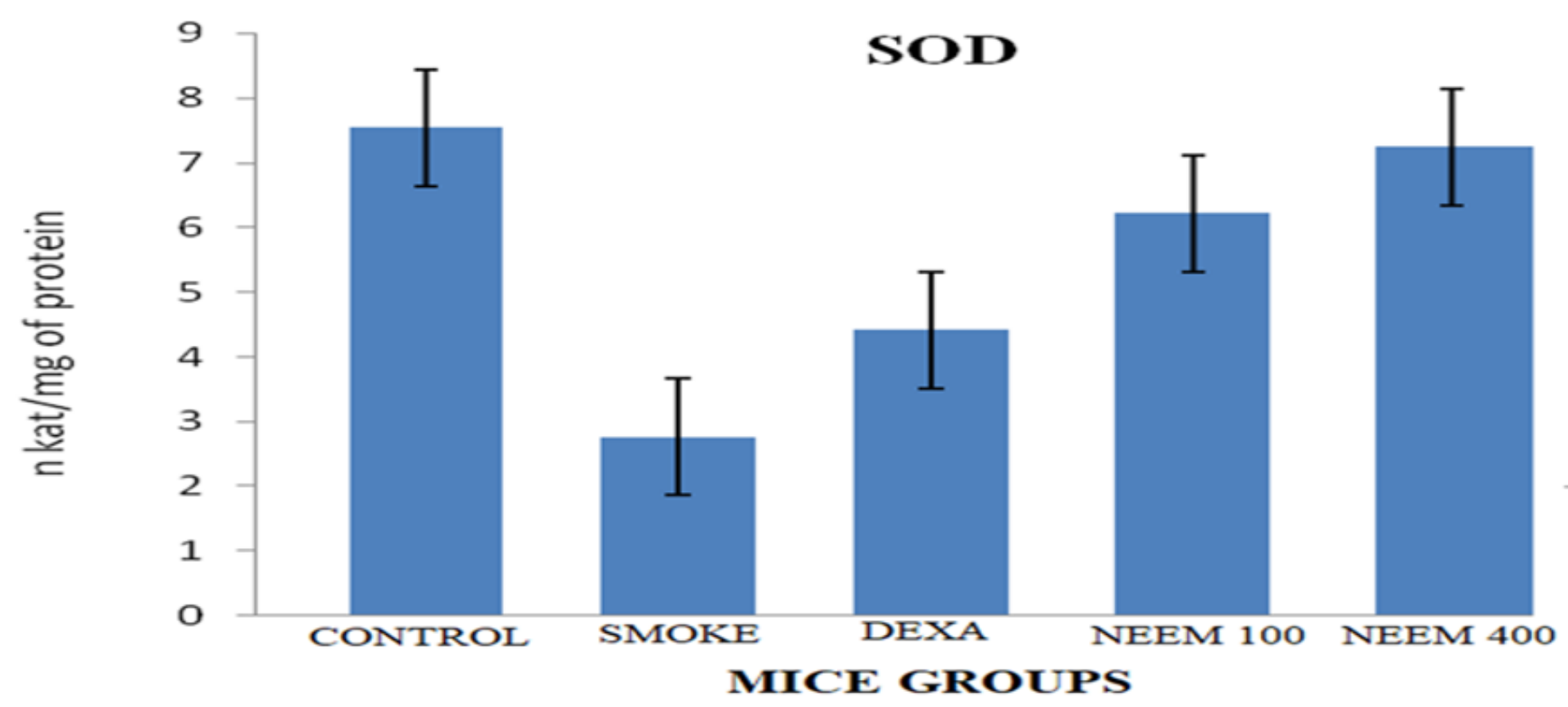

Figure 9

Effect of Dexamethasone and $A$. indica on SOD activity in smoke-induced liver injury.

\section{Supplementary Files}

This is a list of supplementary files associated with this preprint. Click to download.

- GraphicalAbstract.tiff 